\title{
Factors Affecting Level of Participation in the Management of Mangroves as Ecotourism Attraction: Lesson Learned from Cengkrong Watulimo, Trenggalek
}

\author{
Muhammad Izzuddin Faizal ${ }^{1 *}$, Luchman Hakim², Nuddin Harahap ${ }^{3}$ \\ ${ }^{1}$ Master Program of Environmental Sciences, University of Brawijaya, Malang, Indonesia \\ ${ }^{2}$ Department of Biology, Faculty of Mathematics and Natural Sciences, University of Brawijaya, Malang, Indonesia \\ ${ }^{3}$ Faculty of Fisheries and Marine Science, University of Brawijaya, Malang, Indonesia
}

\begin{abstract}
Ecotourism development can not be separated from the social aspects of the people living around the tourist sites. One indicator that a tourist location is said to be ecotourism-based is the participation of community in the activities of management. This study aims to determine the effect of variables that exist on the level of community participation in the management of mangrove areas Cengkrong using Partial Least Square (PLS) method. The variables used in this study are: community characteristics, perceptions, norms, patterns of social relationships, and trust. From the research, the variables that have a dominant influence on the level of participation in the management of mangrove Cengkrong is variable of perceptions, norms, and trusts with the value of the effect size, respectively for $0.098,0.204$, and 0.431 . While variable of trust has most influence to the coefficient path of community participation with a value of 0.64 .
\end{abstract}

Keywords: Ecotourism, Factors of Participation, Level of Participation, Partial Least Square (PLS).

\section{INTRODUCTION}

Cengkrong mangrove area is one of the ecotourism-based objects for tourist destination located in Cengkrong coastal area. As the ecotourism area, Cengkrong mangrove areas have an important role not only for the natural balance of coastal areas, but also for the economy of the people living around the mangrove areas [1,2]. Ecotourism development requires social acceptance that the successful development of ecotourism requires community participation [3]. The settlements of people who live around the conservation area have function as a buffer area. Without the participation of the community, the negative effect in the form of excessive use of natural resources that could damage the existing resources, degrade the quality of the ecology in the area, causing an imbalance in economic growth and cultural erosion. Tourism activities should be able to enhance the role of the community in order to avoid threats to the region and tourism through which exerts a positive impact of increased revenues, improved public infrastructure and empowerment of the local culture.

Community participation in the development process is influenced by many factors. Internal factors affecting such characteristics include age, education level and monthly income.

\footnotetext{
*Correspondence address:

Muhammad Izzuddin Faizal

Email : izza.faizal1993@gmail.com

Address : Graduate School University of Brawijaya, Mayjen Haryono 169, Malang65145
}

Besidesthat, other influential factors are perception, and social capital (norms, patterns of relationship and trust). The stages of participation in the development process are explained as follows. The participation is in the planning stage, implementation stage, deployment stage, and assessment of development stage [4].

Recent grows of mangrove tourism management has been identified as an important strategy for community participation development. It is due to nomerous tourist visit and economic benefit derived from tourism activity. Mangrove tourism in Karanggandu Village has been grown as an important variant of tourism product. Demand for natural-based tourism increase significantly. It is important to study the community participation for future sustainable management practices of mangrove tourism. The aims of the research was to analyze the variables that influence level of community participation, and variables that affect the dominant level of community participation in mangrove Cengkrong, Karanggandu Village, Sub district Watulimo of Trenggalek Regency. It is especially important for sustainable mangrove tourism planning and management.

\section{MATERIAL AND METHOD Study area}

Research was done in Karanggandu Village, Sub district Watulimo of Trenggalek Regency (Fig.1). This village has wide coastal dan mangrove area which is used as tourism 
destination sites. Mangrove area in Karanggandu Village was about 87 ha. Most people in Karanggandu Village has job that related with tourism activity in the mangrove area. The development of local community participation in mangrove Cengkrong area was adderessed to improve local community prosperity; in which local people involve and receive benefit from tourism activity. Following the potential site of coastal environment in Karanggandu Village as ecotourism site, local authority and coomunity proposed such area as ecotourism destination in Trenggalek Regency called Ecotourism of Mangrove Cengkrong. Recently, this area is one of the favorite tourism sites in Trenggalek Regency.

\section{Variables Identification}

The variables used in this study consisted of a latent variable $(X)$ and the measured variables or indicators $(Y)$. The variables in the study are presented in Table 1.

To measure characteristic variable, we identified the characteristic respondents to indicate their level of age, monthly income, and their education using a 5-point Likert-type scale.To measure variable of perception, norms, patterns of social relations, trust and participation, we asked respondent to indicates their level agreement using 5-point Likert-type scale, ranging from strongly disagree to strongly agree. The following items of instrument to measure variables was given in Table 1.

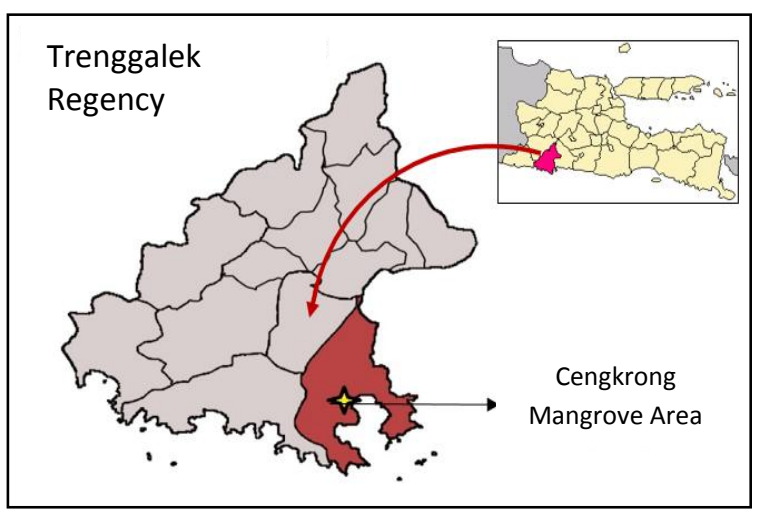

Figure 1. Location of Study Area

Table 1. Latent Variables and Indicators

\begin{tabular}{|c|c|c|}
\hline Latent variables & Variables measured (indicators) & Definition \\
\hline \multirow{3}{*}{ Characteristics $\left(\mathrm{X}_{1}\right)$} & Age $\left(X_{1.1}\right)$ & Age of respondents \\
\hline & Monthly income $\left(X_{1.2}\right)$ & Respondent income in one month \\
\hline & Education $\left(\mathrm{X}_{1.3}\right)$ & Formal education respondents \\
\hline \multirow{9}{*}{ Perception $\left(X_{2}\right)$} & Knowledge $1\left(\mathrm{X}_{2.1}\right)$ & $\begin{array}{l}\text { Respondents' knowledge regarding the benefits of the economic } \\
\text { existence of mangroves for communities }\end{array}$ \\
\hline & Knowledge $2\left(X_{2.2}\right)$ & $\begin{array}{l}\text { Knowledge of respondents associated the influence of the mangrove } \\
\text { ecosystem for social life }\end{array}$ \\
\hline & Knowledge $3\left(X_{2.3}\right)$ & $\begin{array}{l}\text { Knowledge of respondents associated the influence of mangrove } \\
\text { ecosystems for coastal environmental quality }\end{array}$ \\
\hline & Knowledge $4\left(X_{2.4}\right)$ & $\begin{array}{l}\text { Respondents' knowledge regarding the benefits of mangrove } \\
\text { ecosystems for coastal fauna }\end{array}$ \\
\hline & Knowledge $5\left(\mathrm{X}_{2.5}\right)$ & Related respondents' knowledge of ecotourism \\
\hline & Attitudes $1\left(X_{2.6}\right)$ & The attitude of the respondents with the activities of travel \\
\hline & Attitude $2\left(X_{2.7}\right)$ & The attitude of the respondents with their tourism development \\
\hline & Attitude $3\left(X_{2.8}\right)$ & The attitude of the respondents to the development of ecotourism \\
\hline & Attitudes $4\left(\mathrm{X}_{2.9}\right)$ & The attitude of the respondents to the management activities \\
\hline \multirow{4}{*}{$\operatorname{Norm}\left(X_{3}\right)$} & Family rules $\left(\mathrm{X}_{3.1}\right)$ & The rules applicable in the family \\
\hline & The rules of society $\left(X_{3.2}\right)$ & The rules that apply in the community \\
\hline & Norms of decency $\left(X_{3.3}\right)$ & Norms of decency held \\
\hline & Government regulations $\left(X_{3.4}\right)$ & Government rules that apply \\
\hline \multirow{4}{*}{$\begin{array}{l}\text { Patterns of Social } \\
\text { Relations }\left(\mathrm{X}_{4}\right)\end{array}$} & Relations with neighbors $\left(\mathrm{X}_{4.1}\right)$ & Conditions relations with neighbors \\
\hline & Mutual support between neighbors $\left(X_{4.2}\right)$ & Daily activities that involve neighbors \\
\hline & Social activeness $\left(\mathrm{X}_{4.3}\right)$ & Activeness in following the activities of the village \\
\hline & Community involvement $\left(\mathrm{X}_{4.4}\right)$ & The involvement of local communities in managing \\
\hline \multirow{5}{*}{ Trust $\left(X_{5}\right)$} & Openness $\left(X_{5.1}\right)$ & Openness towards tourists \\
\hline & Confidence in the manager $\left(\mathrm{X}_{5.2}\right)$ & $\begin{array}{l}\text { Confidence in the management of the manager in managing the } \\
\text { region }\end{array}$ \\
\hline & Fairness in decision-making $\left(X_{5.3}\right)$ & Business fair in making decisions involving the common interests \\
\hline & $\begin{array}{l}\text { Willingness to follow the direction of the } \\
\text { manager }\left(X_{5.4}\right)\end{array}$ & People want to implement directives and advice from area manager \\
\hline & Confidence in the local government $\left(X_{5.5}\right)$ & $\begin{array}{l}\text { Public trust in government that facilitates the development of rural } \\
\text { area management }\end{array}$ \\
\hline \multirow{4}{*}{$\begin{array}{l}\text { Participation Stage } \\
\text { (Y) }\end{array}$} & Planning $\left(\mathrm{Y}_{1}\right)$ & Participation in planning activities \\
\hline & Implementation $\left(\mathrm{Y}_{2}\right)$ & Participation in the implementation of activities \\
\hline & Utilization of results $\left(\mathrm{Y}_{3}\right)$ & Participation in the activities of utilization of the results \\
\hline & Evaluation $\left(\mathrm{Y}_{4}\right)$ & Participation in evaluation activities \\
\hline
\end{tabular}


The population of this study is that the village community Karanggandu involved in management mangroveCengkrong areas totaling 120 people. For sampling using purposive sampling, while the determination of the number of samples using methods Slovin [5]:

$$
n=\frac{120}{120(0,05)^{2}+1}=92 \text { sample }
$$

\section{Description:}

$\mathrm{n}$ = sample

$\mathrm{N}=$ population (120 people)

$d=$ the value of precision of $95 \%$ or 0.05

\section{Quality Data Test}

\section{Validity Test}

The validity test of an instrument has done by result of output from PLS model which shows thediscriminant validity (AVE roots and the correlation between the latent variables). Discriminant validity is a value that measure how much the variable influence another variable [6].

\section{Reliability Test}

Instrument reliability test resulted by composite reliability from the output model of PLS. The instrument has a high degree of reliability if the value obtained reliability coefficient $>0.60$ [7].

\section{Processing and Data Analysis with PLS Approach}

PLS is a component-based SEM or variance analysis method that is not based on many assumptions. The purpose of the PLS is to test the theory of the weak and weak data such as the small sample size or a problem in the normality of the data, predicting the effect of variable $X$ (exogenous) to $Y$ (endogenous variable) and explain the relationship theoretical between these two variables [8].

\section{Research hypothesis}

Statistical hypothesis for the inner model of latent exogenous variables (independent) against endogenous variable (dependent) in this study are:

$\mathrm{H}_{0}:$ $ү \mathrm{i}=0$ opponents $\mathrm{H} 1: \gamma \mathrm{i} \neq 0$

$H_{1}$ : There is the influence of variables $X$ (exogenous) to the level of community participation.

$H_{0}$ : There is no influence between variable $X$ (exogenous) to the level of community participation

\section{RESULTS AND DISCUSSION}

Cengkrong mangrove area as one of ecotourism-based area in Trenggalek Regency has an effort management area, i.e. a Community Group Supervisor (Pokmaswas) Kejung Samudera which is partner of the Department of Marine and Fisheries in Trenggalek. Moreover, because Cengkrong mangrove areas included in the area of forestry area, then Indonesia State Owned Forest Entreprises (Perhutani) also participated in the activities of mangrove Cengkrong area management. They formed Forest Village Community Institution ( $L M D H)$ Gunung Madu. Collaborative management of these two groups is expected to manage the mangrove areas Cengkrong well.

\section{Characteristics of Respondents}

Number of questionnaires distributed as many as 92 respondents. Questionnaires were distri-buted to the people living around the Cengkrong mangrove areas and aged over 16 years. The village community profile Karanggandu who became respondents in this study isshow in Table 2.

\section{Analysis Method with PLS}

\section{Evaluation Criteria Goodness of Fit}

Evaluation of Goodness of Fit Outer Model

Evaluation Goodness of Fit on the outer models with reflective indicators evaluated by discriminant validity and composite reliability with the following results (Table 3 and 4).

Table 2. Distribution of the Respondent Characteristics

\begin{tabular}{cccc}
\hline Characteristics & Interval & Total (respondent) & Percentage (\%) \\
\hline \multirow{2}{*}{ Age } & $20-35$ & 11 & $12 \%$ \\
& $36-50$ & 52 & $57 \%$ \\
& $51-65$ & 29 & $32 \%$ \\
\hline \multirow{3}{*}{ Monthly Income (Rupiah) } & $<1000000$ & 55 & $60 \%$ \\
& $1000000-2000000$ & 34 & $37 \%$ \\
& $>2000000$ & 3 & $3 \%$ \\
\hline \multirow{2}{*}{ Level of education } & Elementary School & 35 & $38 \%$ \\
& Junior High School & 23 & $25 \%$ \\
& Senior High School-Degree & 34 & $37 \%$ \\
\hline
\end{tabular}




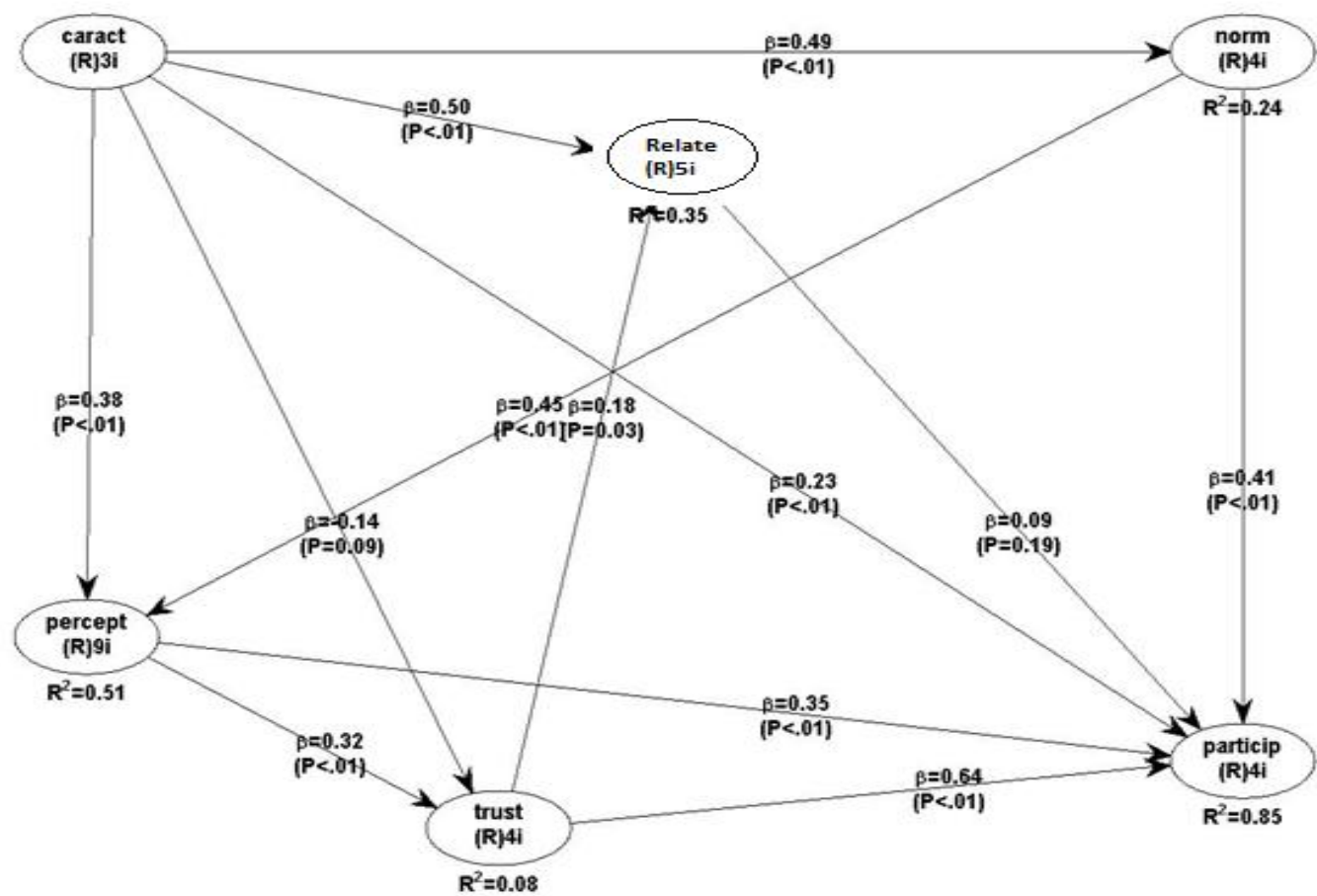

Figure 2. Diagram Construction of PLS Path Modeling

Table 3. Discriminant Validity Results Test

\begin{tabular}{lcccccc}
\hline & Characteristics & Perception & Norms & Relationship patterns & Trust & Participation \\
\hline Characteristics & $0.771^{*}$ & 0.583 & 0.479 & 0.526 & 0.196 & 0.310 \\
Perception & 0.583 & $0.613^{*}$ & 0.609 & 0.529 & 0.366 & 0.279 \\
Norms & 0.479 & 0.609 & $0.856^{*}$ & 0.689 & 0.146 & 0.325 \\
Relationship patterns & 0.526 & 0.529 & 0.689 & $0.859^{*}$ & 0.314 & 0.430 \\
Trust & 0.196 & 0.366 & 0.146 & 0.314 & $0.727^{*}$ & 0.663 \\
Participation & 0.310 & 0.279 & 0.325 & 0.430 & 0.663 & $0.767^{*}$ \\
\hline
\end{tabular}

*Square root of AVE

Discriminant validity of the measurement model reflective indicators assessed by cross loading which compares the value of cross loading of each indicator against the construct is greater than the value of cross loading indicator to construct or other latent variables. The output of the discriminant validity can be seen in Table 3.

Discriminant validity can be seen from the root of AVE (Average Variance Extracted) on a larger diagonal column depend correlations among constructs in the same column. The table shows that the root of AVE on the diagonal column is higher than the correlation between the latent variables in a column other than the diagonal (off-diagonal). This indicates discriminant validity is met.

Composite reliability is a reliability test in PLS which shows the accuracy, consistency of the accuracy of a measuring instrument in measuring [9]. The results of the composite reliability can be seen in Table 4.Composite reliability is good if it has value of more than 0.7 .

\begin{tabular}{cc}
\multicolumn{2}{c}{ Table 4. } \\
\hline Variable & Composite reliability \\
\hline $\mathrm{X}_{1}$ & 0.812 \\
$\mathrm{X}_{2}$ & 0.837 \\
$\mathrm{X}_{3}$ & 0.916 \\
$\mathrm{X}_{4}$ & 0.934 \\
$\mathrm{X}_{5}$ & 0.804 \\
$\mathrm{Y}$ & 0.781 \\
\hline
\end{tabular}

\section{Evaluation of Goodness of Fit Inner Model}

Goodness of fit inner modelsR-square is evaluated using latent dependent variable and using $Q$-square predictive relevance to demonstrate that the construct used is a construct that has a good predictive relevance and feasible for use in research. Q-square value must be $>0$ which indicates the model has predictive relevance good [6]. R-square value of the result of analysis using PLS software Warp 5.0. R-squared values were obtained in Table 5. 
Table 5. R-square Result

\begin{tabular}{lcccccc} 
& $\begin{array}{c}\text { Characteristic } \\
\left(\mathbf{R}_{\mathbf{1}}\right)\end{array}$ & $\begin{array}{c}\text { Perception } \\
\left(\mathbf{R}_{\mathbf{2}}\right)\end{array}$ & $\begin{array}{c}\text { Norms } \\
\left(\mathbf{R}_{\mathbf{3}}\right)\end{array}$ & $\begin{array}{c}\text { Relationship patterns } \\
\left(\mathbf{R}_{\mathbf{4}}\right)\end{array}$ & $\begin{array}{c}\text { Trust } \\
\left(\mathbf{R}_{\mathbf{5}}\right)\end{array}$ & $\begin{array}{c}\text { Participation } \\
\left(\mathbf{R}_{\mathbf{6}}\right)\end{array}$ \\
\hline R-squared & 0 & 0.512 & 0.235 & 0.346 & 0.083 & 0.851 \\
\hline
\end{tabular}

Furthermore, the acquisition of $R^{2}$ inserted into the $Q$-square following equation:

Q2 $\quad=1-\left(1-R 1^{2}\right) *\left(1-R 2^{2}\right) *\left(1-R 3^{2}\right) *\left(1-R 4^{2}\right) *\left(1-R 5^{2}\right) *\left(1-R 6^{2}\right)$

$=1-\left(1-0^{2}\right) *\left(1-0.512^{2}\right) *\left(1-0.235^{2}\right) *\left(1-0.346^{2}\right) *\left(1-0.083^{2}\right) *\left(1-0.851^{2}\right)$

$=1-(1-0) *(1-0.74) *(1-0.94) *(1-0.88) *(1-0.99) *(1-0.28)$

$=0.8319$

Based on the results of the calculation of the value of the $\mathrm{Q}$-square can be seen that the $\mathrm{Q}$ square value of 0.8319 . This shows that the inner goodness of fit of the model study factors affecting the level of public participation can be predicted well by the variable characteristics, perceptions, norms, patterns of social relationships and trust with a value of $83.19 \%$. While $16.81 \%$ predicted by other variables outside studied.

\section{Discussion}

Hypothesis testing is done by comparing the effect size that appears at the output modeling results. Output effect size presents the results $f$ squared effect size [10]. Effect size can be grouped into three categories: weak (0.02), medium (0.15), and large (0.35) [11,12] effect size values below 0.02 indicate that latent variable effect is very weak predictor of practical view despite having a significant $p$ value.

Based on estimates indicate that the characteristic has the effect size of 0.229 to perception, characteristic to the norm of 0.235 , and characteristics of the social relationship of 0.283 . These results belong to a group effect sizelarge enough to show the characteristic variable has a considerable influence on the perception, norms and patterns of social relations. Variable characteristics have a weak effect on the variable trust (0.036) and participation (0.077).

Perception variable have an influence on the variables of trust with a medium effect size value of 0.119 . While the perception variable has effect size of 0.098 includes enough participation. Norms variable have a large effect size on the perception variable $(0.283)$ and participation (0.204). Otherwise, variable pattern of social relationships has weak influence on participation variable (0.040). The variable of trust has a weak effect size (0.063) on the pattern of social relations variable and the large effect size (0.431) against participation variable.
In an effort to increase community participation in the management of Cengkrong mangrove areas, required efforts from the management and the government to improve the public perception related to tourism activities and management activities in Cengkrong mangrove areas Cengkrong. Public perception identified in this study relates to the knowledge and attitudes the community in tourist activities and Cengkrong mangrove management activities. Activity-based development of the area managers and the government in the form of socialization activities related to tourism management plan and management of mangrove areas Cengkrong overall. Developmentsactivities are expected to improve public knowledge in the management of Cengkrong mangrove areas effort and can make people have an attitude that is able to support the activities and management of Cengkrong mangrove tourism

Test result effect size showed that the variables that have a considerable influence on community participation is variable perceptions, norms, and trusts. A person's perception is closely related to the choice in decision-making [13] so that when people have a good perception of mangrove Cengkrong management activities, then the public will also be encouraged to participate in it.

Beside that, adherence to social norms and trusts that are part of the social capital of the community must also be increased in order to ensure continuity of community participation in the management of mangrove Cengkrong. Efforts to improve the adherence to the norms and social trust can be done by strengthening family function [14] and ensure one's social life in society [15]. Family function is meant is to ensure rules that apply remain adhered to and maintained within the family and the community [16]. Compliance with existing norms in the order of daily life is expected to ensure the livelihood of the people and inter-community relations can be maintained. 
Social trust should be maintained and enhanced in an effort to ensure public participation in the management of Cengkrong mangrove areas. Social trust can be built by establish good communication within the community, openness between the manager of the community, and real support from the government on the management of Cengkrong mangrove areas.

\section{CONCLUSION}

Variables used in this modeling are the characteristics of the respondent, perceptions, norms, patterns of social relationships, and trust. Based on the results of studies showed that the variables that have a strong influence on the level of community participation in the management of mangrove areas Cengkrong is norms and trustsvariables. The dominant influence on the level of community participation in the management of mangrove areas Cengkrong is variable trust with path coefficient value of 0.64 .

The management of mangrove Cengkrong in Karanggandu Village should increase the effort of community participation. Program should be paid to community development which contributes to the mangrove Cengkrong management. The community in Karanggandu Village should be involved in mangrove management. Communitybased tourism can be an effective strategy to involve community in mangrove Cengkrong management.

\section{REFERENCES}

[1] Wood, M. E. 1998. Meeting the global challenge of community participation in ecotourism: Case studies and lessons from Ecuador. Verde America Working Paper Series. The Nature Conservancy. Arlington VA.

[2] Jacobson, S. K. and R. Robles. 1992. Ecotourism, sustainable development, and conservation education: Development of a tour guide training program in Tortuguero, Costa RicaEnvironmental Management 16 (6), 701-713.

[3] Rahardjo, B. 2004. Ekoturisme berbasis masyarakat dan pengelolaan sumberdaya alam. Salman Jaya.Bandung.

[4] Cohen, J. M. and N. T. Uphoff. 1977. Rural development participation:concepts and measures for project design, implementation and evaluation. Rural Development
Monograph No. 2. Rural Development Committee Center for International Studies. Cornell University.

[5] Riduwan. 2005. Belajar mudah penelitian untuk guru, karyawan, dan peneliti pemula. Alfabeta. Bandung.

[6] Malhotra, N. (2012). Basic Marketing Research. (4th ed.). Saddle River: Pearson Prentice Hall. Intl.

[7] Friedman, M. 2010. Textbook of family nursing: research, theory, and practice, $5^{\text {th }}$ Ed. EGC.Jakarta.

[8] Abdi, H. 2003. Partial Least Squares (PLS) Regression. Sage.Thousand Oaks.

[9] Jogiyanto, H. M. and A. Willy. 2009. Konsep dan aplikasi PLS (Partial Least Square) untuk penelitian empiris. BPFE.Yogyakarta.

[10] Cohen, J. 1992. A power primer. Psycological Bulletin 112, 155-159.

[11] Hair, J., T. Hult, C. Ringle and M. Sartstedt. 2013. A Partial Least Square premier on Structural Equation Modeling (PLS-SEM). Sage.Los Angeles.

[12] Kock, N. 2013. Advanced mediating effects test, multi-group analyzes, assessment and measurement models in PLS-based SEM. ScriptWarp Systems.Laredo, TX.

[13] Ghozali, I. 2006. Structural Equation Modeling, alternative method with Partial Least Square, $1^{\text {st }} \mathrm{Ed}$. Diponegoro University Publishers Agency.Semarang.

[14] Hablemitoglu S. and F. Yildirim. 2008. The relationship between perception of risk and decision making styles of turkish university students: a descriptive study of individual differences. World Applied Science Journal 4 (2), 214-224.

[15] Santoso, S. 2004.Dinamika Kelompok.Bumi Aksara. Jakarta.

[16] Rochaniningsih, N. S. Dampak pergeseran peran dan fungsi keluarga pada perilaku menyimpang remaja. Jurnal Pembangunan Pendidikan: Fondasi dan Aplikasi 2 (1), 5971. 